\title{
Fabricating Different Laminate Composites by Manual Layup and Estimating the Optimum Parameters for CNC Milling Machine
}

\author{
Ghadak M. Alkhafaji1*, Fathi A. Alshammaa ${ }^{2}$, Enas A. Khalid ${ }^{3}$
}

\section{Authors affiliations:}

1*) Automated Manufacturing Engineering Department, University of Baghdad, Baghdad, Iraq. ghadakmohammad8@gmail.com,

2) Mechanical Engineering Department, University of Baghdad, Baghdad, Iraq.

fathyalshamma@gmail.com

3) Automated Manufacturing Engineering Department, University of Baghdad, Baghdad, Iraq. enaslaser77@kecbu.uobaghdad.edu.iq

\section{Paper History:}

Received: $21^{\text {st }}$ June 2020

Revised: $4^{\text {th }}$ Sep. 2020

Accepted: $21^{\text {st }}$ Nov. 2020

\begin{abstract}
In this paper the ability of fabricating laminate composites by manual layup was discussed. Heating method was used to manufacture the composites; heat was applied to approximately 12 hours with specific heat temperature. There were four types of laminate composites fabricated and studied in this research, containing Aluminum alloy 6061 as the common element in all types, two types of fibers; woven Carbon fiber with two different orientations: $\pm 45^{\circ}, \pm 60^{\circ}$, random fiberglass and with two types of resin; epoxy resin and polyester resin. Different types of composites were made to determine the effect of $\mathrm{CNC}$ milling machine to the measured surface roughness and for specified parameters. The weight fraction ratio of the fibers is $37 \%$, polymer is $34 \%$ and $29 \%$ for Aluminum. The parameters selected are spindle speed, feed rate and depth of cut. The L9 Taguchi orthogonal arrays, signal to noise $(\mathrm{S} / \mathrm{N})$ ratio and analysis of variance (ANOVA) are selected to determine the effect of these parameters; it was analyzed by MINITAB 17 program. The results showed that the parameter were significant more to the epoxy resin specimens than polyester resin specimens. The optimal milling parameters for good surface finish for Aluminum - Carbon fiber composite are at 3000RPM, $1200 \mathrm{~mm} / \mathrm{min}, 1.2 \mathrm{~mm}$, and for Aluminum - Fiberglass composite are 5000RPM, $1800 \mathrm{~mm} / \mathrm{min}, 2.0 \mathrm{~mm}$.
\end{abstract}

Keywords: Surface Roughness, CNC Milling Machine, Heating Method, Laminate Composites, Manual Layup.

$$
\begin{aligned}
& \text { تصنيع المواد المركة المختلفة عن طريق القولة اليدوية وإيجاد المتغيرات المثلى } \\
& \text { لماكنة التفريز الرقية } \\
& \text { غدق محمد عباس، فتحي عبدالصاحب الشماع، إيناس عبدالكريم خالد النه }
\end{aligned}
$$




\section{Introduction}

Composite material are structural materials can be divided into four basic categories: metals, polymers, ceramics, and composites. Composites, which consist of two or more separate materials combined in a structural unit, are typically made from various combinations of the other three materials. Composite materials are usually classified according to the type of reinforcement used [1]. Fiber Metal Laminates (FML) is a kind of hybrid materials and it can be fabricated from an alternating laminate of thin metal sheets and thin composite layers. Since several variables are involved in the composition of this laminate, a wide range of different combinations lamination seems to be possible. Some of these variables are the type of metal alloy, the type of fibers, the type of polymer, the thickness of layers, the number of layers, the orientation of fiber layers. Therefore, FMLs are regarded as a family of laminates, and GLARE and Carbon Fiber Reinforced Polymer (CFRP) are the best- known member of these laminates [2].

Soltani et al. [3] in this paper, the carbon fiber and epoxy had been used as the material. Methodology of this paper is an industrially accessible out-of-autoclave carbon fiber epoxy was utilized to create laminated composites and a co cure and secondary composites bonding cohesive was utilized as resin. The composites were first cured at $122^{\circ} \mathrm{C}$ for 1 hour and subsequently post cured for two hours at temperatures going from $122^{\circ} \mathrm{C}$ to $177^{\circ} \mathrm{C}$. It was seen that the short beam shear strength of the cured laminated composites expanded by expanding the post-restoring temperature.

Ashok Rai et al. [4] this work deals with a random arranged fiberglass example has been set up so that the strands are in direct contact of the resin. Holes of different diameters were done $(10,12$, $16 \mathrm{~mm}$ ) by $\mathrm{CNC}$ processing machine, Taguchi structure with L9 orthogonal array is utilized for the analyses. The four parameters taken in processing of fiberglass sheet are tool radius, cutting velocity, and depth of cutting and feeds. The optimization of parameters has been accomplished with the assistance of main effects plots using Taguchi design and ANOVA tables in order to discover which parameter has affected the most for increasing the surface finish. The results showed that surface roughness increase with increase of the feed rate, surface roughness decreases with increase of tool diameter and the rest of the parameters were not as significant as The feed rate and tool diameter.

Jenarthanan and Jeyapaul [5] this exploration work desire to discover the machinability in processing way of GFRP laminates produced with the assistance of hand lay-up. An arrangement of analyses dependent on Taguchi was set up and the processing was performed with prefixed parameters. An analysis of variance (ANOVA) has been utilized to explore the effect of cutting parameters on surface roughness. The objective is to assess the machinability of GFRP laminate in normal for spindle speed, feed rate, fiber direction $\left(15^{\circ}, 60^{\circ}\right.$ and $\left.105^{\circ}\right)$, and solid carbide with mill gear about $25^{\circ}, 35^{\circ}$ and $45^{\circ}$ helix angle, to ensure a useful machinability list. The results showed that surface roughness increase with increase of fiber direction and the helix angle and the feed rate.

Tan et al. [6] the author in his research used woven carbon fibers, woven E-glass fibers, in EpoxAmite matrix and hardener resin as the materials. The direction of woven carbon (C) and glass $(\mathrm{G})$ fibers were organized in the grouping of [CGCG] these fibers were stacked in the glass mold until thickness $4 \mathrm{~mm}$ has been accomplished and they were fixed and compacted with vacuum sack under a vacuum from 11 to $15 \mathrm{mBar}$. Response surface methodology (RSM) was used in finding the exact connections between test parameters and surface roughness dependent on the Taguchi results. Three parameters had been selected with three levels; spindle speed, feed rate and tool geometry with L27 orthogonal array. The test examinations showed that surface roughness is incredibly affected by feed rate and tool geometry instead of the spindle speed. Surface roughness increase with increase of feed rate.

Hassan et al. [7] in this research, the material used in the manufacturing GLARE are woven Eglass fiber, epoxy resin and aluminum alloys sheet of $0.5 \mathrm{~mm}$ thickness. The GLARE composites are fabricated using hand layup technique. Mainly, the treatment of aluminum surface should be taken into consideration upon fabrication procedure because it is a dominant factor to increase de-bonding between aluminum and other component of the composite material. The proposed procedures for manufacturing the GLARE material is an effective and having good durability. Increasing the number of glass fiber composite laminates gives good strengths but increases the thickness of the whole specimen, results in weakening the specimen in form of delamination failures. Plasticity regions are affected with increasing number of glass fiber composite laminates.

Christke et al. [8] in this paper the materials used were $6.35 \mathrm{~mm}$ Aluminum alloy 2024 and CFRP with and without polymer metal laminate (PML) thermal protection. The metal substrate was Aluminum alloy rolled plate cut into $600 \mathrm{~mm}$ long, $50 \mathrm{~mm}$ wide test specimens. The CFRP was fabricated from unidirectional carbon fiber-epoxy prepreg tape. The advantage of the PML is that, in non-fire conditions, it contributes to the appearance and load-bearing capability of the structure without being at risk to damage or water absorption.

Azghan and Eslami-Farsani [9] the aim of this paper is to examine the impacts of various stacking sequence and thermal cycling at the flexural residences of FMLs. FMLs had been made out of 
two aluminum 2024 sheets and epoxy resin that have four layers of basalt as well as glass strands with 5 different stacking sequences. For FML tests the thermal process duration was around $6 \mathrm{~min}$. Temperature cycles were from $25{ }^{\circ} \mathrm{C}$ to $115^{\circ} \mathrm{C}$. The discoveries showed that flexural modulus were most extreme for basalt strands principally based FML, least for glass fibers, basically based FML simultaneously as basalt/glass fibers based FML lies between them. After thermal cycling, due to the great thermal residences of basalt strands, flexural properties of basalt filaments based of FML structures decreased lesser than various composites.

Prasanth et al. [10] the authors studied the milling of GFRP composites due to becoming basic and necessary so as to upgrade its surface quality by improving its dimensional tolerances, and limiting the surface imperfections. this work`s examinations were done to upgrade the four significant processing parameters, spindle speed, feeds and depth of cut and sort of processing device on a surface roughness $R_{a}$. Taguchi L25 orthogonal arrays was utilized for design of experiments, and investigation of variance (ANOVA) has been utilized to distinguish the commitment of each considered parameters on execution the parameter optimization, spindle speed $=1950 \mathrm{rpm}$, feed $\mathrm{rate}=1 \mathrm{~mm} / \mathrm{s}$, depth of cut $=$ $=1 \mathrm{~mm}$, and tool type as two-fluted brazed carbide tipped end mill. Surface roughness decreased with increase of spindle speed. $R_{a}$ increased with increase of feed rate.

In this research, the optimum parameters for each type of laminate composite material for milling process had been estimated and the also effect of the parameters to the measured surface roughness have been analyzed. Manufacturing of several types of laminate composite has been studied, with different layers of carbon fiber and fiberglass which have been used with common metal as the aluminum alloy 6061, and the epoxy resin and polyester resin as the binder. Three parameters selected were; spindle speed, feed rate and depth of cut applied on nine experiments. Experiments had been carried out by make a groove by $\mathrm{CNC}$ milling machine onto the composite and measure the surface roughness after each experiment, then by MINITAB17 the optimum parameters were found by the $\mathrm{S} / \mathrm{N}$ ratios and ANOVA tables.

\section{Materials and Methodology}

Materials used in this research are: Aluminum alloy 6061 with $0.1 \mathrm{~mm}$, as the metal in all the composites. In addition to fibers as in figure (1) (a) and (b), two types had been chosen, Random Fiberglass and also continues woven carbon fiber in $\pm 45^{\circ}$ orientation and $\pm 60^{\circ}$ orientation. And the resins, first, Epoxy (Sikadur $\left.{ }^{\circledR}-52\right)$ that is two parts, solvent free, low viscosity as in figure (1) (c); Secondly, polyester resin part A and part B as in figure (1) (d).

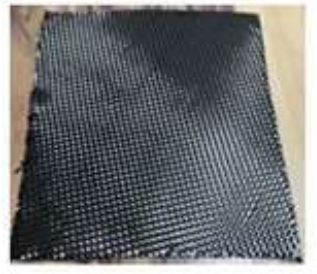

(a)

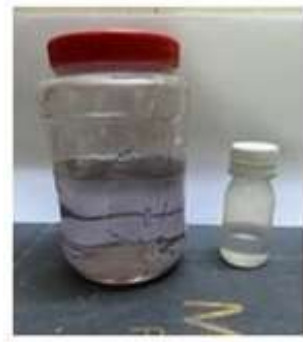

(c)

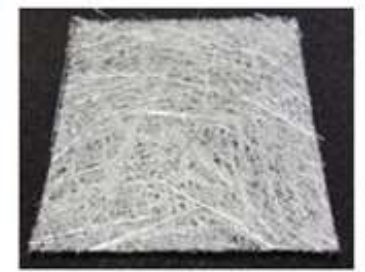

(b)

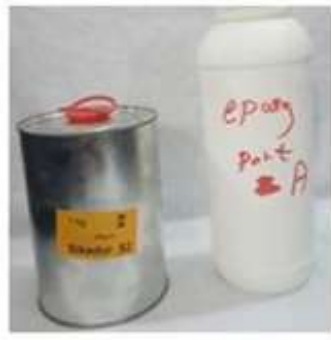

(d)
Figure (1): (a) woven carbon fiber, (b) random fiberglass, (c) polyester resin, (d) epoxy resin.

Surface preparation is necessary for good coherence between the layers. The aluminum alloy 6061 is smooth in surface, so it had been roughened with an iron brush to get a better surface for the fabrication process as illustrated in figure (2).

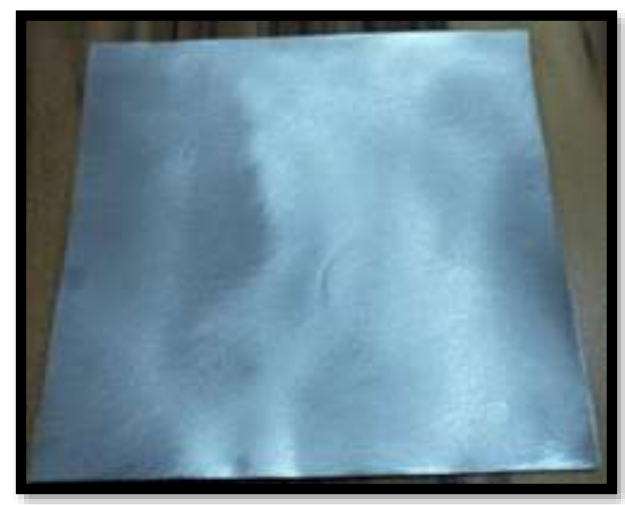

Figure (2): Aluminum alloy after surface treatment.

Four different specimens, with $100 \times 100 \mathrm{~mm}$ and thickness of $2.8 \mathrm{~mm}$, that had been made up manually. Multiple Layers were stacked together using hand layup in the four specimens depending on the weight of the fiber used, the weight fraction ratio of the fibers is $37 \%$, polymer is $34 \%$ and $29 \%$ for Aluminum.. Stacking sequence was in certain order and different orientation angles as described in Table (1) and figure (3) and (4). To begin the manufacturing, first releasing agent must be applied on the glass mold to prevent the workpieces from sticking in the mold, the specimens were made by applying some of the resin on the aluminum alloy layer and then on the fiber layer till the last layer of aluminum as in figure (5), after that the specimen was placed in a glass mold and then in the oven for curing. The heating method included applying heat to the composites, then immediately specimens were placed in the oven at $52^{\circ} \mathrm{C}$ for 5 hrs. then followed by $74^{\circ} \mathrm{C}$ for $6 \mathrm{hrs}$., depending on the researcher work Patil et al. [11] and Baumert et al. [12], the epoxy resin mixing ratio was $2: 1$ and polyester resin was 
50:1 then the specimen is left in open air for 7 days for full solidification of the resin. The four specimens are shown in figure (6).

Table (1): Stacking sequence of the layers.

\begin{tabular}{|c|c|c|}
\hline $\begin{array}{c}\text { Composite } \\
\text { material }\end{array}$ & $\begin{array}{l}\text { Fiberglass- } \\
\text { Aluminum } \\
\text { Seven Layers } \\
\end{array}$ & $\begin{array}{c}\text { Carbon fiber- } \\
\text { Aluminum } \\
\text { Nineteen Layers }\end{array}$ \\
\hline $\begin{array}{c}\text { Stacking } \\
\text { sequence } \\
\text { from bottom } \\
\text { to top }\end{array}$ & $\begin{array}{l}\text { aluminum alloy, } \\
\text { fiberglass, } \\
\text { fiberglass, } \\
\text { aluminum alloy, } \\
\text { fiberglass, } \\
\text { fiberglass, } \\
\text { aluminum alloy. }\end{array}$ & $\begin{array}{l}\text { aluminum alloy, } \\
+45,+60,-45,-60, \\
+45,+60,-45,-60 \\
\text { Carbon fiber, } \\
\text { aluminum alloy, } \\
-60,-45,+60,+45 \text {, } \\
-60,-45,-60,+45 \\
\text { Carbon fiber, } \\
\text { aluminum alloy. }\end{array}$ \\
\hline
\end{tabular}

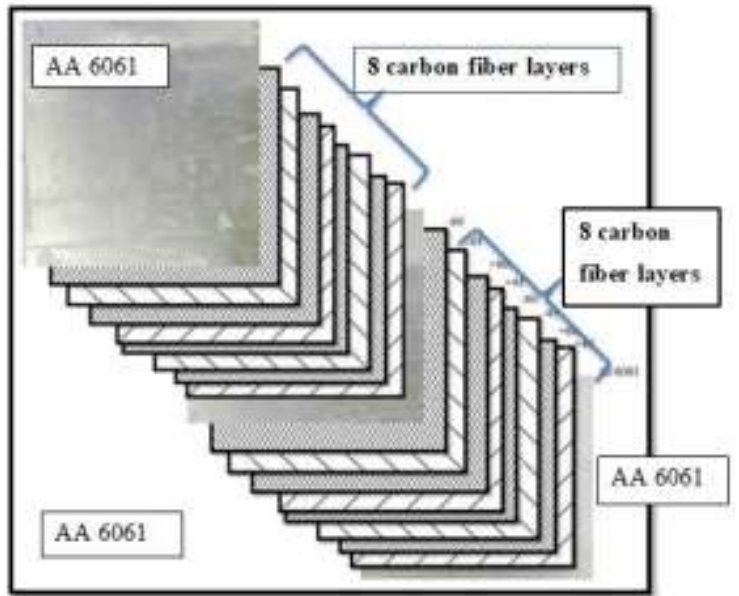

Figure (3): Stacking sequence of the layers for carbon fiber workpiece.

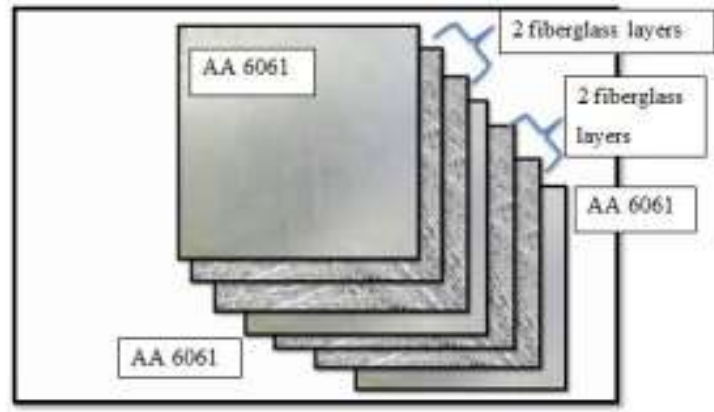

Figure (4): Stacking sequence of the layers for fiberglass workpiece.

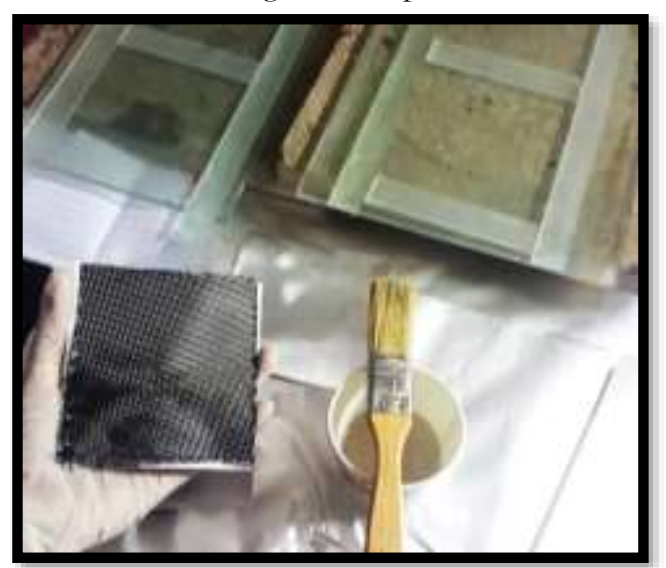

Figure (5): Manual layup of composite specimen.

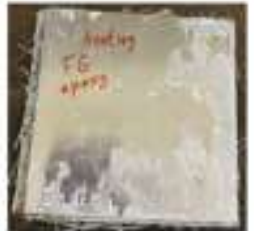

(a)

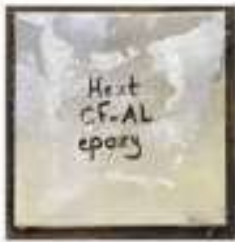

(c)

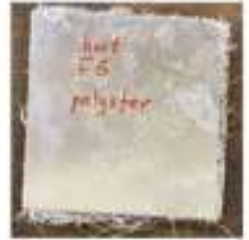

(b)

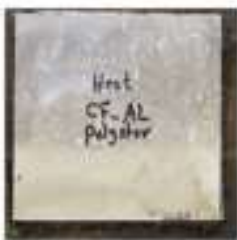

(d)
Figure (6): (a) fiberglass-aluminum with epoxy resin specimen. (b) fiberglass-aluminum with polyester resin specimen, (c) carbon fiber-aluminum with epoxy resin specimen, (d) carbon fiber-aluminum with polyester resin specimen.

\section{Experimental design}

CNC Milling Machine, A vertical CNC milling machine model ACCUWAY UM-85, were used to perform the experimental work as shown in figure (7). Uncoated Carbide end mill cutter was used with diameter $6 \mathrm{~mm}$; and the number of flutes is 4 . Figure (8) shows the end mill cutter.

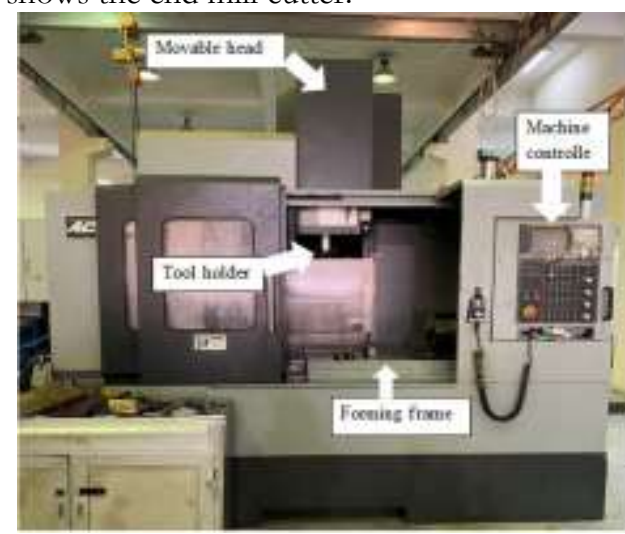

Figure (7): CNC milling machine.

\section{Design of experiments (DOE)}

The objective of using DOE is to find the optimum parameters for the milling process to get smallest surface roughness of machined surface using the smaller the better, as in the equation bellow [13].

$$
\frac{\mathbf{s}}{\mathrm{N}}=-\mathbf{1 0} \log \left(\frac{1}{\mathrm{n}} \sum_{\mathrm{i}=\mathbf{1}}^{\mathrm{n}} \mathrm{x}^{2}\right) \ldots \ldots \ldots \ldots \text { smaller is }
$$

Where $\mathrm{n}$ is the number of observations and $\mathrm{x}$ is the observed data [13]. After manufacturing the specimens, experiments are curried out to select the optimum parameters for each composite workpiece. Desgin of Experiments (DOE) and Taguchi method had been used to minimize experiment number and also to find the optimum parameter for the surface roughness. In this study L9 orghogonal array (OA) has been used and three parameters with three levels have been selected to apply on the composites. Table (2) describes the parameters and their levels. 
Table (2): Input parameters and levels.

\begin{tabular}{|l|l|l|l|l|}
\hline Parameters & Symbol & $\begin{array}{l}\text { Level } \\
\mathbf{1}\end{array}$ & $\begin{array}{l}\text { Level } \\
\mathbf{2}\end{array}$ & $\begin{array}{l}\text { Level } \\
\mathbf{3}\end{array}$ \\
\hline $\begin{array}{l}\text { Spindle speed } \\
\text { (r.p.m) }\end{array}$ & A & 3000 & 4000 & 5000 \\
\hline $\begin{array}{l}\text { Feed rate } \\
\text { (mm/min) }\end{array}$ & B & 800 & 1200 & 1600 \\
\hline $\begin{array}{l}\text { Depth of cut } \\
\text { (mm) }\end{array}$ & C & 1.2 & 1.6 & 2.0 \\
\hline
\end{tabular}

\section{Surface roughness}

The surface roughness of the nine experiments for each composite were measured by using roughness measuring device POCKET SURF shown in figure (8). Four values were measured to each groove in a certain order as illustrated in figure (9), for all the experiments and analyzed using MINITAB 17 software.

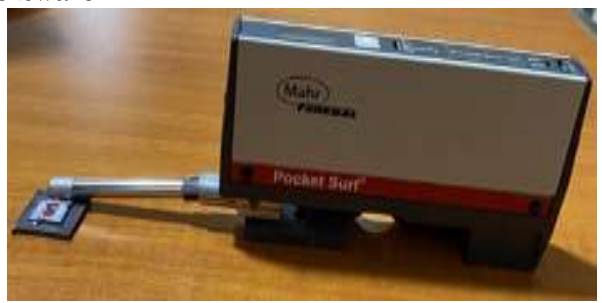

Figure (8): Surface roughness tester.

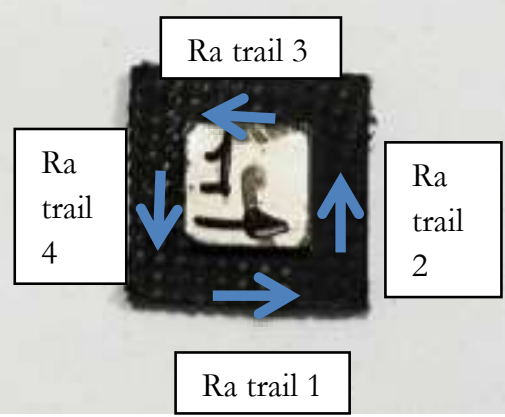

Figure (9): Measured Ra values for a single experiment.

\section{Results and discussion}

The composites that had been manufactured from heat method and after the milling process the results showed that, the measured surface roughness for the carbon fiber $\left(\mathrm{Ra}_{\min , \mathrm{CF}}=1.92 \mu \mathrm{m}\right)$ has a better value than the fiberglass $\left(\mathrm{Ra}_{\min , \mathrm{FG}}=3.1 \mu \mathrm{m}\right)$ due to the nature and characteristics of each fiber. The effect of the parameters on surface roughness of the composite after the milling is that the surface roughness decrease with the increase of spindle speed as in the researchers [13] and [14]. Surface roughness increases with the increase of feed rate and depth of cut as in [4] and [10]. After the milling, the separation between the layers have been in sixteen experiments of thirty six experiments. Table (3) illustrated the contribution results for each composite type.

Table (3): Contribution results for the composites.

\begin{tabular}{|c|c|c|c|c|}
\hline \multirow{2}{*}{ Parameter } & \multicolumn{2}{|c|}{ Contribution } & \multicolumn{2}{c|}{ Contribution } \\
\cline { 2 - 5 } & \multicolumn{2}{|c|}{ Epoxy resin } & \multicolumn{2}{c|}{ Polyester resin } \\
\cline { 2 - 5 } & CF-Al & FG-Al & CF-Al & FG-Al \\
\hline A & $42 \%$ & $6 \%$ & $23 \%$ & $31 \%$ \\
\hline
\end{tabular}

\begin{tabular}{|c|c|c|c|c|}
\hline $\mathbf{B}$ & $45 \%$ & $70 \%$ & $15 \%$ & $35 \%$ \\
\hline $\mathbf{C}$ & $12 \%$ & $23 \%$ & $60 \%$ & $32 \%$ \\
\hline R-sq & $97 \%$ & $83 \%$ & $62 \%$ & $55 \%$ \\
\hline
\end{tabular}

A. Fiberglass-Aluminum with epoxy resin composite

For this composite specimens the optimum parameters for the best surface roughness are A3B3C3 (A3=5000r.p.m, B3 $=1600 \mathrm{~mm} / \mathrm{min}$, C3 $=2 \mathbf{m m}$ ) that is illustrated in figure (10). The nine experiments that had been applied to the composite and the measured surface roughness, four values for each experiment, are all listed in table (4) and the input parameters with their results of $\mathrm{Ra}$ are illustrated in table (5). The experiments work well in the final square shape, but there are fiber burr in most of the experiments, also separation occurs only in Exp. 9, the last layer have been a fiber layer, that means two layers were separated from the base square. As seen in table (6) and (7), SN ratios and ANOVA tables, showed results of the significant factors, F-value and P-value and contribution of each parameter. Feed rate is the most significant factor by $70 \%$, while spindle speed affects the lowest by $6 \%$. Model summary of the process leads to that R-sq is $83 \%$.

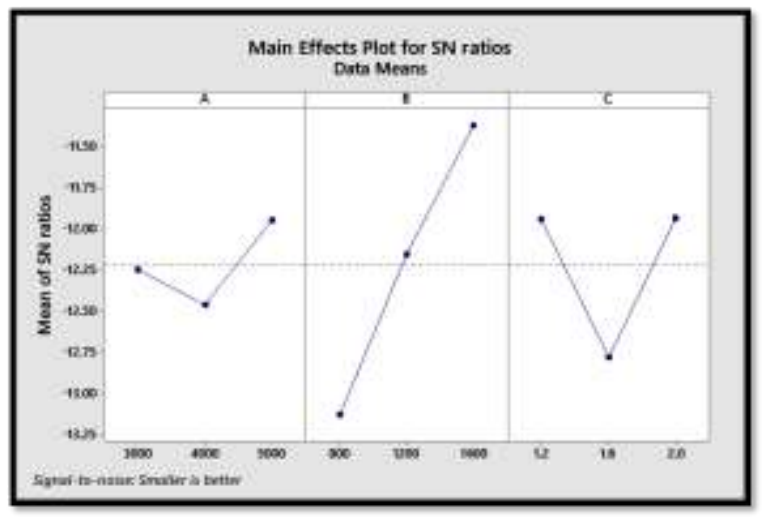

Figure (10): Main effect plots for $\mathrm{SN}$ (y-axis) ratios of the parameters ( $\mathrm{x}$-axis) for $\mathrm{FG}-\mathrm{Al}$ with epoxy.

Table (4): Surface roughness results for FG-Al with epoxy.

\begin{tabular}{|c|c|c|c|c|c|}
\hline Exp. & $\begin{array}{c}\text { Ra1 } \\
(\mu \mathrm{m})\end{array}$ & $\begin{array}{r}\text { Ra2 } \\
(\mu \mathrm{m})\end{array}$ & $\begin{array}{r}\text { Ra3 } \\
(\mu \mathrm{m})\end{array}$ & $\begin{array}{r}\mathrm{Ra} 4 \\
(\mu \mathrm{m})\end{array}$ & $\begin{array}{l}\mathbf{R a}_{\mathrm{Av}} \\
(\mu \mathrm{m})\end{array}$ \\
\hline$\# 1$ & 4.27 & 4.77 & 5.37 & 2.93 & 4.335 \\
\hline$\# 2$ & 4.12 & 4.21 & 5.72 & 4.41 & 4.615 \\
\hline$\# 3$ & 4.97 & 1.88 & 3.46 & $\mathrm{Hi}$ & 3.436 \\
\hline \#4 & 4.33 & 4.95 & 5 & 4.74 & 4.755 \\
\hline$\# 5$ & 3.97 & 2.06 & 3.86 & 5.98 & 3.967 \\
\hline \#6 & 3.22 & 3.8 & 4.47 & 4.21 & 3.925 \\
\hline \#7 & 6.38 & 3.3 & 3.34 & 5.07 & 4.522 \\
\hline \#8 & 2.91 & 5.78 & 3.01 & 2.84 & 3.635 \\
\hline \#9 & 3.88 & $\mathrm{Hi}$ & 2.61 & 4.82 & 3.77 \\
\hline
\end{tabular}

Table (5): The input parameters and the output $\mathrm{Ra}$

\begin{tabular}{|c|c|c|c|c|c|}
\hline Exp. & $\begin{array}{c}\text { Spindle } \\
\text { speed } \\
(\text { r.p.m) }\end{array}$ & $\begin{array}{c}\text { Feed rate } \\
(\mathbf{m m} / \mathbf{m i n})\end{array}$ & $\begin{array}{c}\text { Depth } \\
\text { of cut } \\
(\mathbf{m m})\end{array}$ & $\begin{array}{c}\text { Ra } \\
(\mu \mathrm{m})\end{array}$ & $\begin{array}{c}\text { Ra } \\
\text { pred. } \\
(\mu \mathrm{m})\end{array}$ \\
\hline$\# 1$ & 3000 & 800 & 1.2 & 4.33 & 4.907 \\
\hline$\# 2$ & 3000 & 1200 & 1.6 & 4.61 & 5.307 \\
\hline
\end{tabular}




\begin{tabular}{|c|c|c|c|c|c|}
\hline \#3 & 3000 & 1600 & 2 & 3.43 & 5.707 \\
\hline \#4 & 4000 & 800 & 1.6 & 4.75 & 4.907 \\
\hline \#5 & 4000 & 1200 & 2 & 3.96 & 5.307 \\
\hline \#6 & 4000 & 1600 & 1.2 & 3.92 & 5.707 \\
\hline \#7 & 5000 & 800 & 2 & 4.52 & 4.907 \\
\hline \#8 & 5000 & 1200 & 1.2 & 3.63 & 5.307 \\
\hline \#9 & 5000 & 1600 & 1.6 & 3.77 & 5.707 \\
\hline
\end{tabular}

Table (6): Response table for $\mathrm{SN}$ ratios for FG-Al with epoxy.

\begin{tabular}{|c|c|c|c|}
\hline Level & A & B & C \\
\hline $\mathbf{1}$ & -12.25 & -13.13 & -11.94 \\
\hline $\mathbf{2}$ & -12.46 & -12.15 & -12.78 \\
\hline $\mathbf{3}$ & -11.95 & -11.38 & -11.93 \\
\hline Rank & 3 & 1 & 2 \\
\hline
\end{tabular}

Table (7): ANOVA results for FG-Al with epoxy.

\begin{tabular}{|c|c|c|c|c|c|c|}
\hline Source & DF & Adj SS & Adj MS & $\begin{array}{c}\text { F- } \\
\text { value }\end{array}$ & $\begin{array}{c}\mathbf{P}- \\
\text { value }\end{array}$ & 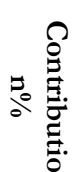 \\
\hline $\mathbf{A}$ & 2 & 0.08859 & \begin{tabular}{|l|}
0.04429 \\
\end{tabular} & 0.31 & 0.763 & $6 \%$ \\
\hline B & 2 & 1.03107 & 0.51553 & 3.61 & 0.217 & $70 \%$ \\
\hline $\mathrm{C}$ & 2 & 0.33591 & 0.16796 & 1.18 & 0.456 & $23 \%$ \\
\hline Error & 2 & 0.28531 & \begin{tabular}{|l|}
0.14266 \\
\end{tabular} & & & \\
\hline Total & 8 & 1.74088 & & & & \\
\hline
\end{tabular}

\section{B. Fiberglass-Aluminum with polyester resin composite}

For this composite the optimum parameters for the best surface roughness are A3B2C1 (A3 $=5000$ r.p.m, B2 $=1200 \mathrm{~mm} / \mathrm{min}, \mathrm{C} 1=1.2 \mathrm{~mm}$ ) that is illustrated in figure (11). The nine experiments that had been applied to the composite and the measured surface roughness, four values for each experiment, are all listed in table (8) and the input parameters with their results of $\mathrm{Ra}$ are illustrated in table (9). The experiments work well in the final square shape, but there are fiber burr in most of the experiments. Also separation occurs but in Exp.4 and Exp. 5 no separated layers in the square. But in Exp.1 and Exp. 2 only the first layer of metal has been separated. Also separation occurs in Exp.3, Exp.5, Exp.7, and Exp.9, three layers had been separated from the square. As seen in table (10) and (11), S/N ratio and ANOVA tables showed results of the significant factors, F-value and P-value and contribution of each parameter. All the parameters were almost at the same effect $33 \%$, the parameters are not so effective on the output value due to the Rsq number, which is $55 \%$ only.

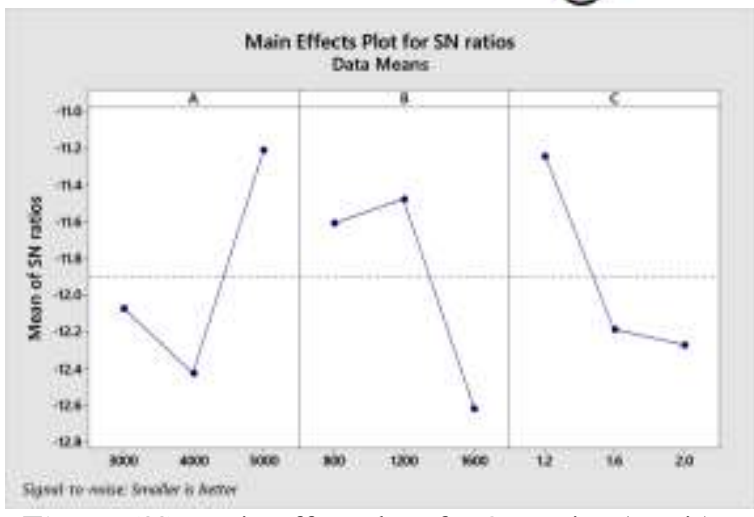

Figure (11): Main effect plots for $\mathrm{SN}$ ratios (y-axis) of the parameters (x-axis) for $\mathrm{FG}-\mathrm{Al}$ with polyester.

Table (8): Surface roughness results for FG-Al with

\begin{tabular}{|c|c|c|c|c|c|}
\hline Exp. & $\begin{array}{c}\text { Ra 1 } \\
(\boldsymbol{\mu m})\end{array}$ & $\begin{array}{c}\text { Ra 2 } \\
(\boldsymbol{\mu m})\end{array}$ & $\begin{array}{c}\text { Ra 3 } \\
(\boldsymbol{\mu m})\end{array}$ & $\begin{array}{c}\text { Ra 4 } \\
(\boldsymbol{\mu m})\end{array}$ & $\begin{array}{c}\mathbf{R a}_{\text {Av. }} \\
(\boldsymbol{\mu m})\end{array}$ \\
\hline$\# \mathbf{1}$ & 4.54 & 4.56 & 3.9 & 3.02 & 4.005 \\
\hline$\# \mathbf{2}$ & 4.16 & 2.81 & 3.78 & 3.49 & 3.56 \\
\hline$\# \mathbf{3}$ & 5.43 & 5.15 & 3.74 & 3.8 & 4.53 \\
\hline$\# \mathbf{4}$ & 4.57 & 3.95 & 4.47 & 3.63 & 4.155 \\
\hline$\# \mathbf{5}$ & 3.14 & 4.57 & 6.19 & $\mathrm{Hi}$ & 4.633 \\
\hline$\# \mathbf{6}$ & 3.28 & 4.78 & 2.57 & 4.54 & 3.792 \\
\hline$\# \mathbf{7}$ & 3.17 & 3.18 & 2.24 & 4.62 & 3.302 \\
\hline$\# \mathbf{8}$ & 2.9 & 4.07 & 1.3 & 4.49 & 3.19 \\
\hline$\# \mathbf{9}$ & 5.64 & 5.99 & 2.24 & 4.31 & 4.545 \\
\hline
\end{tabular}

Table (9): The input parameters and the output Ra for FG-Al polyester.

\begin{tabular}{|c|c|c|c|c|c|}
\hline Exp. & $\begin{array}{c}\text { Spindle } \\
\text { speed } \\
\text { (r.p.m) }\end{array}$ & $\begin{array}{l}\text { Feed rate } \\
(\mathrm{mm} / \mathrm{min})\end{array}$ & $\begin{array}{l}\text { Depth } \\
\text { of cut } \\
\text { (mm) }\end{array}$ & $\begin{array}{l}\text { RaAv. } \\
(\mu \mathrm{m})\end{array}$ & $\begin{array}{c}\text { Ra } \\
\text { pred. } \\
(\mu \mathrm{m})\end{array}$ \\
\hline \#1 & 3000 & 800 & 1.2 & 4.005 & 3.968 \\
\hline$\# 2$ & 3000 & 1200 & 1.6 & 3.56 & 3.968 \\
\hline \#3 & 3000 & 1600 & 2 & 4.53 & 3.968 \\
\hline$\# 4$ & 4000 & 800 & 1.6 & 4.155 & 3.968 \\
\hline$\# 5$ & 4000 & 1200 & 2 & 4.633 & 3.968 \\
\hline \#6 & 4000 & 1600 & 1.2 & 3.792 & 3.968 \\
\hline \#7 & 5000 & 800 & 2 & 3.302 & 3.968 \\
\hline$\# 8$ & 5000 & 1200 & 1.2 & 3.19 & 3.968 \\
\hline \#9 & 5000 & 1600 & 1.6 & 4.545 & 3.968 \\
\hline
\end{tabular}

Table (10): Response table for $\mathrm{SN}$ ratios for FG-Al with polyester.

\begin{tabular}{|l|l|l|l|}
\hline Level & A & B & C \\
\hline $\mathbf{1}$ & -12.07 & -11.60 & -11.24 \\
\hline $\mathbf{2}$ & -12.42 & -11.47 & -12.18 \\
\hline $\mathbf{3}$ & -11.20 & -12.62 & -12.27 \\
\hline Rank & 1 & 2 & 3 \\
\hline
\end{tabular}

Table (11): ANOVA results for FG-Al with polyester.

\begin{tabular}{|c|c|c|c|c|c|c|}
\hline Source & DF & $\begin{array}{c}\text { Adj } \\
\text { SS }\end{array}$ & $\begin{array}{c}\text { ADj } \\
\text { MS }\end{array}$ & $\begin{array}{c}\text { F- } \\
\text { Value }\end{array}$ & $\begin{array}{c}\text { P- } \\
\text { value }\end{array}$ & Contribution\% \\
\hline A & 2 & 0.4151 & 0.2076 & 0.39 & 0.720 & $31.75 \%$ \\
\hline B & 2 & 0.4648 & 0.2324 & 0.44 & 0.696 & $35.55 \%$ \\
\hline C & 2 & 0.4275 & 0.2137 & 0.40 & 0.714 & $32.69 \%$ \\
\hline Error & 2 & 1.0658 & 0.5329 & & & \\
\hline Total & 8 & 2.3732 & & & & \\
\hline
\end{tabular}




\section{Carbon fiber-Aluminum with epoxy resin composite}

For this composite the optimum parameters for the best surface roughness are $\mathbf{A 1 B 2 C 1}$ (A3=3000r.p.m, B2 $=1200 \mathrm{~mm} / \mathrm{min}, \mathrm{C} 1=1.2 \mathrm{~mm}$ ) that is illustrated in figure (12) and the input parameters with their results of $\mathrm{Ra}$ are illustrated in table (12).. The nine experiments that had been applied to the composite and the measured surface roughness, four values for each experiment, are all listed in table (13). The experiments work well in the final square shape. Also separation occurs in Exp.1 and Exp. 2 just the first layer of metal was separated from the square. For Exp. 8 the large square was separated into two parts, from the middle metal layer. For Exp.3, Exp.4, Exp.5, Exp.6 and Exp.7 the separation occurs from the middle layer of the metal that means ten layers were separated from the square. As seen in table (14) and (15), $\mathrm{S} / \mathrm{N}$ ratio and ANOVA tables showed results of the significant factors, F-value and P-value and contribution of each parameter. Spindle speed and feed rate has almost the same effect $43 \%$, the parameters are effective on the output value due to the R-sq number, which is $97 \%$.

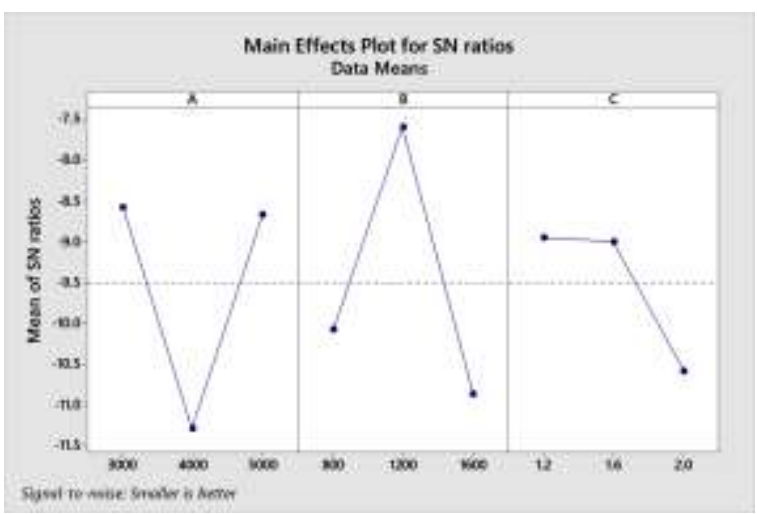

Figure (12): Main effect plots for $\mathrm{SN}$ ratios (y-axis) of the parameters (x-axis) for $\mathrm{CF}-\mathrm{Al}$ with epoxy.

Table (12): Surface roughness results for $\mathrm{CF}-\mathrm{Al}$ with

\begin{tabular}{|c|c|c|c|c|c|}
\hline Exp. & $\begin{array}{c}\text { Ra 1 } \\
(\boldsymbol{\mu m})\end{array}$ & $\begin{array}{c}\text { Ra 2 } \\
(\boldsymbol{\mu m})\end{array}$ & $\begin{array}{c}\text { Ra 3 } \\
(\boldsymbol{\mu} \mathbf{m})\end{array}$ & $\begin{array}{c}\text { Ra 4 } \\
(\boldsymbol{\mu} \mathbf{m})\end{array}$ & $\begin{array}{c}\mathbf{R a}_{\text {Av. }} \\
(\boldsymbol{\mu m})\end{array}$ \\
\hline$\# \mathbf{1}$ & 4.19 & 1.73 & 2.62 & 2.24 & 2.695 \\
\hline$\# \mathbf{2}$ & 3.46 & 1.29 & 2.92 & 0.13 & 1.95 \\
\hline$\# \mathbf{3}$ & 6.08 & 2.63 & Hi & 2.35 & 3.686 \\
\hline$\# \mathbf{4}$ & 6.15 & 2.82 & 4.6 & 1.73 & 3.825 \\
\hline$\# \mathbf{5}$ & 3.48 & 2.89 & Hi & 3.64 & 3.336 \\
\hline$\# \mathbf{6}$ & 3.65 & 3.56 & 2.74 & 5.53 & 3.87 \\
\hline$\# \mathbf{7}$ & Hi & 4.1 & 3.17 & 2.19 & 3.153 \\
\hline$\# \mathbf{8}$ & 1.83 & 2.14 & 3.09 & 1.39 & 2.112 \\
\hline$\# \mathbf{9}$ & 2.63 & 3.4 & 2.09 & 3.87 & 2.997 \\
\hline
\end{tabular}

Table (13): The input parameters and the output $\mathrm{Ra}$ for $\mathrm{CF}$-Al epoxy.

\begin{tabular}{|c|c|c|c|c|c|}
\hline Exp. & $\begin{array}{c}\text { Spindle } \\
\text { speed } \\
(\mathbf{r} \cdot \mathbf{p . m})\end{array}$ & $\begin{array}{c}\text { Feed rate } \\
(\mathbf{m m} / \mathbf{m i n})\end{array}$ & $\begin{array}{c}\text { Depth } \\
\text { of cut } \\
(\mathbf{m m})\end{array}$ & $\begin{array}{c}\text { Ra } \\
(\boldsymbol{\mu m})\end{array}$ & $\begin{array}{c}\text { Ra } \\
\text { Pred. } \\
(\boldsymbol{\mu m})\end{array}$ \\
\hline$\# \mathbf{1}$ & 3000 & 800 & 1.2 & 2.69 & 3.069 \\
\hline$\# \mathbf{2}$ & 3000 & 1200 & 1.6 & 1.95 & 3.069 \\
\hline$\# 3$ & 3000 & 1600 & 2 & 3.68 & 3.069 \\
\hline
\end{tabular}

\begin{tabular}{|c|c|c|c|c|c|}
\hline \#4 & 4000 & 800 & 1.6 & 3.82 & 3.069 \\
\hline \# & 4000 & 1200 & 2 & 3.33 & 3.069 \\
\hline \#6 & 4000 & 1600 & 1.2 & 3.87 & 3.069 \\
\hline$\# 7$ & 5000 & 800 & 2 & 3.15 & 3.069 \\
\hline$\# 8$ & 5000 & 1200 & 1.2 & 2.11 & 3.069 \\
\hline$\# 9$ & 5000 & 1600 & 1.6 & 2.99 & 3.069 \\
\hline
\end{tabular}

Table (14): Response table for $\mathrm{SN}$ ratios for $\mathrm{CF}-\mathrm{Al}$ with epoxy.

\begin{tabular}{|l|l|l|l|}
\hline Level & A & B & C \\
\hline $\mathbf{1}$ & -8.582 & -10.080 & -8.954 \\
\hline $\mathbf{2}$ & -11.291 & -7.588 & -8.996 \\
\hline $\mathbf{3}$ & -8.669 & -10.874 & -10.591 \\
\hline Rank & 2 & 1 & 3 \\
\hline
\end{tabular}

Table (15): ANOVA results for $\mathrm{CF}-\mathrm{Al}$ with epoxy.

\begin{tabular}{|c|c|c|c|c|c|c|}
\hline \multirow[b]{2}{*}{ Source } & \multirow[b]{2}{*}{ DF } & \multirow[b]{2}{*}{ Adj SS } & \multirow[b]{2}{*}{ Adj MS } & \multirow[b]{2}{*}{ F-Value } & \multirow[b]{2}{*}{ P-value } & \multirow[b]{2}{*}{ 용 } \\
\hline & & & & & & \\
\hline $\mathbf{A}$ & 2 & 1.66204 & 0.83102 & 19.16 & 0.050 & $42.63 \%$ \\
\hline B & 2 & 1.766204 & 0.88343 & 20.37 & 0.047 & $45.31 \%$ \\
\hline $\mathrm{C}$ & 2 & 0.46980 & 0.23490 & 5.42 & 0.156 & $12.05 \%$ \\
\hline Error & 2 & 0.08675 & 0.04337 & & & \\
\hline Total & 8 & 3.98544 & & & & \\
\hline
\end{tabular}

\section{Carbon fiber-Aluminum with polyester resin composite}

For this composite the optimum parameters for the best surface roughness are $\mathbf{A} 3 \mathbf{B} 2 \mathbf{C 1}$ (A3=5000r.p.m, B2 $=1200 \mathrm{~mm} / \mathrm{min}, \quad C 1=1.2 \mathrm{~mm}$ ) with $\mathrm{Ra}=2.0125 \mu \mathrm{m}$, that is illustrated in figure (13). The nine experiments that had been applied to the composite and the measured surface roughness, four values for each experiment, are all listed in table (16). The experiments work well in the final square shape better than the fiberglass, also separation occurs only in Exp.1. The top ten layers were separated from the square. As seen in table (17) and (18), S/ $\mathrm{N}$ ratio and ANOVA tables showed results of the significant factors, F-value and P-value and contribution of each parameter, F-value showed that neither of the parameter is effective on the surface roughness. Depth of cut has the most effect on the Ra by $60 \%$, and the feed has the lowest effect by $15 \%$. The parameters were not effective on the output value due to the R-sq number, which is $66 \%$.

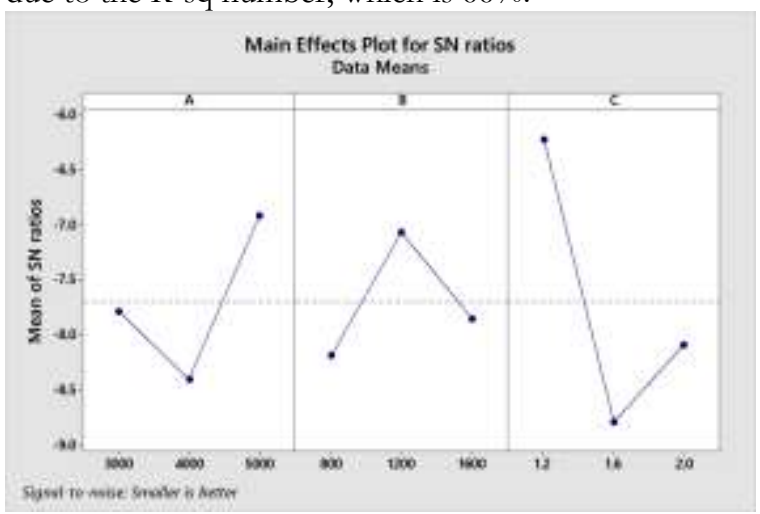

Figure (13): Main effect plots for $\mathrm{SN}$ ratios (y-axis) of the parameters (x-axis) for $\mathrm{CF}-\mathrm{Al}$ with polyester. 
Table (16): Surface roughness results for $\mathrm{CF}-\mathrm{Al}$ with polyester.

\begin{tabular}{|l|l|l|l|l|l|}
\hline Exp. & $\begin{array}{l}\text { Ra 1 } \\
(\boldsymbol{\mu} \mathbf{m})\end{array}$ & $\begin{array}{l}\text { Ra 2 } \\
(\boldsymbol{\mu} \mathbf{m})\end{array}$ & $\begin{array}{l}\text { Ra 3 } \\
(\boldsymbol{\mu} \mathbf{m})\end{array}$ & $\begin{array}{l}\text { Ra 4 } \\
(\boldsymbol{\mu m})\end{array}$ & $\begin{array}{l}\text { Ra } \\
(\boldsymbol{\mu \mathbf { m }})\end{array}$ \\
\hline$\# \mathbf{1}$ & 1.69 & 3.22 & 1.54 & 1.23 & 1.92 \\
\hline$\# \mathbf{2}$ & 1.35 & 1.81 & 5.64 & 1.36 & 2.54 \\
\hline$\# \mathbf{3}$ & 3.03 & 1.4 & 3.04 & 4.61 & 3.02 \\
\hline$\# \mathbf{4}$ & 5.68 & 2.34 & 2.17 & 4.42 & 3.6525 \\
\hline$\# \mathbf{5}$ & 2.14 & 2.09 & 3.81 & 0.94 & 2.245 \\
\hline$\# \mathbf{6}$ & 2.37 & 1.41 & 2.15 & 2.95 & 2.22 \\
\hline$\# \mathbf{7}$ & 3.04 & 2.42 & 1.95 & 2.23 & 2.41 \\
\hline$\# \mathbf{8}$ & 3.94 & 1.54 & 1.02 & 1.55 & 2.0125 \\
\hline$\# \mathbf{9}$ & 2.23 & 2.53 & 1.76 & 2.46 & 2.245 \\
\hline
\end{tabular}

Table (17): The input parameters and the output $\mathrm{Ra}$

\begin{tabular}{|c|c|c|c|c|c|}
\hline Exp. & $\begin{array}{c}\text { Spindle } \\
\text { speed } \\
\text { (r.p.m) }\end{array}$ & $\begin{array}{c}\text { Feed rate } \\
(\mathbf{m m} / \mathbf{m i n})\end{array}$ & $\begin{array}{c}\text { Depth } \\
\text { of cut } \\
(\mathbf{m m})\end{array}$ & $\begin{array}{c}\text { Ra } \\
(\boldsymbol{\mu m} \text { ) }\end{array}$ & $\begin{array}{c}\text { Ra } \\
\text { pred. } \\
(\boldsymbol{\mu m})\end{array}$ \\
\hline \#1 & 3000 & 800 & 1.2 & 1.92 & 2.47 \\
\hline \#2 & 3000 & 1200 & 1.6 & 2.54 & 2.47 \\
\hline \#3 & 3000 & 1600 & 2 & 3.02 & 2.47 \\
\hline \#4 & 4000 & 800 & 1.6 & 3.65 & 2.47 \\
\hline \#5 & 4000 & 1200 & 2 & 2.24 & 2.47 \\
\hline \#6 & 4000 & 1600 & 1.2 & 2.22 & 2.47 \\
\hline \#7 & 5000 & 800 & 2 & 2.41 & 2.47 \\
\hline$\# \mathbf{8}$ & 5000 & 1200 & 1.2 & 2.01 & 2.47 \\
\hline$\# \mathbf{9}$ & 5000 & 1600 & 1.6 & 2.24 & 2.47 \\
\hline
\end{tabular}

Table (18): Response table for $\mathrm{SN}$ ratios for $\mathrm{CF}-\mathrm{Al}$ with polyester.

\begin{tabular}{|l|l|l|l|}
\hline Level & A & B & C \\
\hline $\mathbf{1}$ & -7.788 & -8.186 & -6.223 \\
\hline $\mathbf{2}$ & -8.401 & -7.065 & -8.891 \\
\hline $\mathbf{3}$ & -6.913 & -7.851 & -8.088 \\
\hline Rank & 2 & 3 & 1 \\
\hline
\end{tabular}

Table (19): ANOVA results for CF-Al with polyester.

\begin{tabular}{|c|c|c|c|c|c|c|}
\hline Source & DF & $\begin{array}{c}\text { Adj. } \\
\text { SS }\end{array}$ & $\begin{array}{c}\text { Adj. } \\
\text { MS }\end{array}$ & $\begin{array}{c}\text { F - } \\
\text { value }\end{array}$ & $\begin{array}{c}\text { P- } \\
\text { value }\end{array}$ & Contribution\% \\
\hline A & 2 & 0.3521 & 0.1761 & 0.39 & 0.717 & $23.62 \%$ \\
\hline B & 2 & 0.2360 & 0.1180 & 0.26 & 0.791 & $15.83 \%$ \\
\hline C & 2 & 0.9023 & 0.4511 & 1.01 & 0.491 & $60.54 \%$ \\
\hline Error & 2 & 0.8943 & 0.4471 & & & \\
\hline Total & 8 & 2.3847 & & & & \\
\hline
\end{tabular}

\section{Conclusion}

- Different laminated composite manufacturing have been successful using mold and heating method. The cohesive between the metal and the fiber was good in the final workpiece. A small increase about $0.1 \mathrm{~mm}$ in the depth of the specimens can be noticed due to heating source to the composite without any compression on the mold.

- The effect of the parameters on surface roughness of the composite after the milling is that the surface roughness decrease with the increase of spindle speed, surface roughness increases with the increase of feed rate and depth of cut.
- The best specimen with the most significant parameters is Carbon fiber - Aluminum with epoxy resin, the optimum parameters, spindle speed, feed rate, depth of cut are 3000RPM, $1200 \mathrm{~mm} / \mathrm{min}, 1.2 \mathrm{~mm}$ respectively. After that Fiberglass - Aluminum, epoxy resin comes the second to the effect of parameters. The optimum parameters, spindle speed, feed rate, depth of cut are 5000RPM, $1600 \mathrm{~mm} / \mathrm{min}$, $2.0 \mathrm{~mm}$ respectively.

- For Carbon fiber - Aluminum, and Fiberglass Aluminum, polyester resin specimens the parameters were not significant to the surface roughness. the parameters, spindle speed, feed rate, depth of cut for each specimen are 3000RPM, $1200 \mathrm{~mm} / \mathrm{min}, 1.2 \mathrm{~mm}, 5000 \mathrm{RPM}$, $1200 \mathrm{~mm} / \mathrm{min}, 1.2 \mathrm{~mm}$ respectively.

\section{References}

[1] G. H. Staab, Laminar Composites. ButterworthHeinemann, 1999.

[2] T. Sinmazçelik, E. Avcu, M. Ö. Bora, and O. Çoban, "A review: Fibre metal laminates, background, bonding types and applied test methods," Mater. Des., vol. 32, no. 7, pp. 36713685, 2011.

[3] S. A. Soltani, S. Keshavanarayana, M. T. Krishnamaraja, A. Bhasin, and A. Sriyarathne, "Effect of post-curing temperature variation on mechanical properties of adhesively bonded composite laminates," SAMPE Soc. Adv. Mater. Process Eng. Conf. Proceedings. Oct. 21 - 24 Wichita, Kansas, 2013.

[4] A. Rai, P. Mouria, V. Gulati, and P. Katyal, "Evaluation of milling parameters on fiberglass to reduce the surface roughness," IJIRSET Int. J. Innov. Res. Sci. Eng. Technol., vol. 2, no. 2, pp. 435441, 2013.

[5] M. Jenarthanan and R. Jeyapaul, "Evaluation of machinability index on milling of GFRP Composites with different fibre orientations using solid carbide endmill with modified helix angles," Int. J. Eng. Sci. Technol., vol. 6, no. 4, pp. 1-10, 2014.

[6] C. L. Tan, A. I. Azmi, and N. Muhammad, "Surface roughness analysis of carbon/glass hybrid polymer composites in drilling process based on Taguchi and response surface methodology," Adv. Mater. Res., vol. 1119, pp. 622-627, 2015.

[7] M. K. Hassan, M. Y. Abdellah, S. K. Azabi, and W. W. Marzouk, "Investigation of the mechanical behavior of novel fiber metal laminates," Int. J. Mech. Mechatronics Eng., vol. 15, no. 3, pp. 112118, 2015.

[8] S. Christke, A. G. Gibson, K. Grigoriou, and A. P. Mouritz, "Multi-layer polymer metal laminates for the fire protection of lightweight structures," Mater. Des., vol. 97, pp. 349-356, 2016.

[9] M. A. Azghan and R. Eslami-farsani, "The effects of stacking sequence and thermal cycling on the flexural properties of laminate composites of aluminium-epoxy/basalt-glass fibres," Mater. Res. Express, 2018. 
[10] I. S. N. V. R. Prasanth, D. V. Ravishankar, M. M. Hussain, C. M. Badiganti, V. K. Sharma, and S. Pathak, "Investigations on performance characteristics of GFRP composites in milling," Int. J. Adv. Manuf. Technol., vol. 99, pp. 1351-1360, 2018.

[11] N. A. Patil, S. S. Mulik, K. S. Wangikar, and A. P. Kulkarni, "Characterization of Glass Laminate Aluminium Reinforced Epoxy- A Review," Procedia Manuf., vol. 20, pp. 554-562, 2018.

[12] E. K. Baumert, W. S. Johnson, R. J. Cano, B. J. Jensen, and E. S. Weiser, "Mechanical evaluation of new fiber metal laminates made by the VARTM process," ICCM Int. Conf. Compos. Mater. July 27-31, Edinburgh, Scotland, 2009.

[13] M. Nurhaniza, M. K. A. M. Ariffin, F. Mustapha, and B. T. H. T. Baharudin, "Analyzing the effect of machining parameters setting to the surface roughness during end milling of CFRPAluminium composite laminates," Int. J. Manuf. Eng., vol. 2016, pp. 1-9, 2016.

[14] M. A. Karatas and H. G€okkaya, "A review on machinability of carbon fiber reinforced polymer (CFRP) and glass fiber reinforced polymer (GFRP) composite materials," Def. Technol., vol. 14, pp. 318-326, 2018. 